Тертична Надія Анатоліївна кандидат психологічних наук, доцент, доцент кафедри загальної і медичної психології, Національний медичний університет імені О.О.Богомольця, бульвар Тараса Шевченка, 13, Київ, 01601, тел.: (066) 380-65-25, e-mail: tertichna0405@gmail.com, https://orcid.org/00000002-7326-1522

\title{
ОСОБЛИВОСТІ СТРЕС-ДОЛАЮЧОЇ ПОВЕДІНКИ ЛІКАРЯ В УМОВАХ ПАНДЕМІЇ COVID-19
}

Анотація. Розробка методологічних підходів до діагностики, психокорекції та профілактики станів психологічної дезадаптації та професійної деформації особистості лікарів, які працюють в умовах тривалого та інтенсивного професійного стресу в умовах пандемії COVID-19, є одним із пріоритетних завдань медичної психології. Розгляд цієї проблеми тільки в аспекті негативних наслідків, які виникають у професійній діяльності лікаря під впливом стресу, є, вочевидь, недостатнім. Не менш важливим, на нашу думку, є вивчення механізмів стрес-долаючої поведінки (копінгу), як однієї 3 усвідомлених i активних форм психологічної адаптації фахівця до стресогенних умов життя і професійної діяльності.

Єдиного підходу до класифікації копінг-стратегій в діяльності лікаря на сьогодні в медичній та психологічній літературі не існує. Згідно з позицією Р. Лазарусом та С.Фолькман, у стрес-долаючій поведінці можна виділити два основних аспекти: проблемно-сфокусований і емоційно-сфокусований копінг. Під проблемно-сфокусованим копінгом розуміють спробу поліпшення відносин «людина-середовище», за допомогою зміни когнітивної оцінки ситуації. Емоційно-сфокусований копінг - це думки i дії, метою яких $\epsilon$ зниження фізичного або психологічного впливу стресу.[1]

Також, прийнято розмежовувати активний і пасивний види копінгу. Активний копінг - поведінкові або психологічні відповіді, спрямовані на безпосередню зміну природи стресора або переосмислення ситуації. Численні дослідження з вивчення копінг-стратегій показують, що активні стратегії, будь то поведінкові або емоційні, $є$ конструктивнішими способами взаємодії зі стресовими подіями. У той час, як надавання переваги пасивним стратегіям - $\epsilon$ психологічним фактором ризику або маркером для несприятливих відповідей на стресові події життя та може призвести особистість до адиктивних форм поведінки або психічних станів, які утримують її від адекватного сприймання та вирішення стресових ситуацій.[2] Використання неконструктивної поведінки, ригідних механізмів психологічного захисту у важкій ситуації призводять до наростання стресового навантаження і поступового виснаження 
адаптаційно-компенсаторних ресурсів лікаря, що обумовлює зниження ефективності способів подолання стресу. Тому, вивчення механізмів копінгстратегій лікарів може сприяти пошуку нових напрямків для дослідницької діяльності та віднайдення ресурсів для психологічної підтримки фахівців.

Ключові слова: пандемія COVID-19, копінг-поведінка, професійний стрес, професійна дезадаптація, психологічна адаптація, емоційна компетентність лікаря, психологічна підтримка.

Tertychna Nadiya Anatoliivna PhD, Associate Professor, Associate Professor of the Department of General and Medical Psychology, Bogomolets National Medical University, Taras Shevchenko Boul., 13, Kyiv, 01601, tel.: (066) 380-65-25, e-mail: tertichna0405@gmail.com, https://orcid.org/0000-0002-7326-1522

\section{FEATURES OF DOCTOR'S STRESS-OVERCOMING BEHAVIOR IN A COVID-19 PANDEMIC}

Abstract. The development of methodological approaches to the diagnosis, psychocorrection and prevention of psychological maladaptation and professional personality disorder of doctors working in conditions of prolonged and intense professional stress in a COVID-19 pandemic is one of the priorities of medical psychology. Consideration of this problem only in terms of the negative consequences that arise in the professional activities of a doctor under the influence of stress is obviously insufficient. As important, in our opinion, is the study of the mechanisms of stress-overcoming behavior (coping), as one of the conscious and active forms of psychological adaptation of a person to stressful living conditions and professional activities.

There is no single approach to the classification of coping strategies in the activities of a doctor in the medical and psychological literature. According to the position of Lazarus R., Folkman S. stress-coping behavior has two main aspects: problem-focused and emotionally-focused coping. Problem-focused coping is an attempt to improve the "human-environment" relationship by changing the cognitive assessment of the situation. Emotionally focused coping is a thought and action aimed at reducing the physical or psychological impact of stress. [1]

Also, it is customary to distinguish between active and passive types of coping. Active coping means behavioral or psychological responses aimed at directly changing the nature of the stressor or rethinking the situation. Numerous studies on coping strategies show that active strategies, whether behavioral or emotional, are more constructive ways to interact with stressful events. While giving preference to passive strategies is a psychological risk factor or a marker for adverse responses to stressful life events and can lead a person to addictive behaviors or mental states that prevent from adequate perception and resolving stressful situations. [2] The use of unconstructive behavior, rigid mechanisms of psychological protection in a difficult situation lead to an increase in stress and the gradual depletion of adaptive and compensatory resources of a doctor, which reduces the effectiveness of ways to 
overcome stress. Therefore, studying the mechanisms of coping strategies of doctors can help to find new directions for research and find resources for psychological support.

Keywords: COVID-19 pandemic, coping behavior, professional stress, professional maladaptation, psychological adaptation, emotional competence of a doctor, psychological support.

Постановка проблеми. Стресогенність роботи медичних працівників, 3 одного боку, визначається високими вимогами до професійної компетентності фахівця, інтенсивністю, тривалістю і завантаженістю робочого дня, невисокою заробітною платою; з іншого - високими вимогами до комунікативної та емоційної компетентності лікаря: вміння взаємодіяти 3 пацієнтами, їх родичами та близькими, контакт 3 якими часто несе в собі негативні переживання, а також до оволодіння прийомами управління емоційними станами, прийомами емоційної саморегуляції в професійній діяльності. При тривалому впливі комплексу стресових факторів, а також в зв'язку з високими вимогами до самоефективності лікаря в сучасних умовах, вимогами до вміння передбачати, конструктивно вирішувати i адаптуватися до проблемних ситуацій, у медичних працівників, з високою часткою ймовірності, можуть виникати порушення адаптаційних процесів, пов'язаних 3 деструктивними варіантами у самоставленні та у взаємодії з оточуючим середовищем.

Переживання стресу є індивідуальним для кожної особистості, хоча й має спільні риси. Основною формою прояву зусиль 3 подолання складної ситуації $є$ копінг-поведінка. Копінг-поведінка - поведінка, яка спрямована на пристосування до змінюваних обставин професійної діяльності та передбачає сформоване вміння використовувати певні засоби для подолання емоційного стресу [1]. Така поведінка розглядається як діяльність особистості, спрямована на підтримання або збереження балансу між вимогами середовища та ресурсами, які відповідають цим вимогам, і виявляється в когнітивній, емоційній та поведінковій сферах. Застосування адаптивних варіантів копінгповедінки створює сприятливі умови для подолання станів професійної дезадаптації і формування адекватних стратегій подолання професійного стресу [3].

Аналіз останніх досліджень і публікацій. Аналіз наукових досліджень, що торкаються проблеми використання особистістю ресурсів подолання стресу демонструє, що найбільш вивченими $є$ два шляхи переживання нею негативних переживань, а саме: психологічний захист та психологічне долання (Л.Карамушка, О.Кокун, Т.Ларіна, Г.Ложкін, С.Максименко, Т.Яценко та ін.).

В окресленні характеристик психологічного долання розглядаються як стратегії реагування й поведінки в стресових ситуаціях, що і визначають способи подолання особистістю негативних наслідків стресу, так i 3'ясовуються характерні властивості, які дозволяють сформувати механізми та прийоми ефективного психологічного подолання [3]. 
Мета статті - дослідження особливостей та механізмів використання копінг-стратегій у подоланні стресу лікарями різних спеціальностей в ситуації пандемії COVID-19.

Виклад основного матеріалу. Однією з найважливіших тем у сучасному науковому психологічному просторі $є$ питання стрес-долаючої поведінки у професійній діяльності лікаря. Ситуація, що склалася у зв'язку з пандемією COVID-19, можна сказати, «оголила» низку нагальних проблем, пов'язаних 3 необхідністю надання психологічної допомоги медичним працівникам. Саме постійне перебування лікарів в атмосфері стресу, невизначеності та необхідності проявляти високу ефективність при вирішення нових завдань, вимагає ефективної психологічної відповіді на питання віднайдення можливостей подолання емоційного та фізичного стресу.

Копінг-поведінку розуміємо як цілеспрямовану свідому реакцію на стрес, що виявляє себе в стратегіях, які відповідають характеристикам особистості та ситуації. Копінг-стратегії формуються залежно від інтенсивності стресових подразників, частоти їх виникнення, тривалості, індивідуально-психологічних характеристик самої особистості [4]. Ефективні копінг-стратегії є для лікаря, на нашу думку, не лише ключовим елементом його професійної ефективності, а загалом, чинником збереження психічного здоров'я.

Аналіз різних класифікацій копінг-стратегій дозволяє виділити такі базові стратегії: «вирішення проблем», «пошук соціальної підтримки» й «уникнення». Їх наділяють такими характеристиками [1]:

1. Стратегія вирішення проблем - це активна поведінкова стратегія, застосовуючи яку людина прагне використовувати особистісні ресурси для пошуку можливих способів ефективного вирішення проблеми.

2.Стратегія пошуку соціальної підтримки - це активна поведінкова стратегія, застосовуючи яку людина для ефективного вирішення проблеми звертається по допомогу й підтримку до середовища, яке іiі оточує, - сім'ї, друзів.

3. Стратегія уникнення - це поведінкова стратегія, застосовуючи яку людина прагне уникати контакту з навколишнім світом, витісняє необхідність розв'язання проблеми. До способів уникнення можна віднести занурення у хворобу, вживання алкоголю, наркотиків, варіантом активного способу уникання є суїцид.

Конструктивність або неконструктивність копінг-стратегій лікаря може визначатися тим, наскільки обраний копінг відповідає можливості адаптації й утримання продуктивності діяльності на необхідному рівні, оскільки в цілому передбачається, що «процес подолання життєвих труднощів $є$ процесом мобілізації особистісних ресурсів і ресурсів середовища, i процесом оптимального їх використання» [4].

Наше дослідження було спрямоване на розгляд проблеми вибору лікарями копінг-стратегій у подоланні стресу в професійній діяльності та їх зв'язок зі станами професійної дезадаптації лікарів у ситуації пандемії COVID-19. 
Дослідження проводилося онлайн, у ньому брали участь лікарі різних спеціальностей.

Для реалізації завдань дослідження були використані такі методики: методика «Індикатор копінг-стратегій» (Coping Strategy Indicator, CSI, Д.Амирхан, 1990, в адаптації Н.Сироти, 1994, В. Ялтонського, 1995) [1]; опитувальник трудового стресу А.Б.Леонової та С.Б.Величківської [5]; методика «Вивчення професійної тривоги» (опитувальник Є.Ейдеміллера, I.В.Юстицького) [6]. Додатково була проведена бесіда за результатами опитування, що дозволила нам уточнити певні показники та наповнити психологічний аналіз новими змістовними характеристиками.

За результатами нашого дослідження, домінуючою копінг-стратегією лікарів у боротьбі зі стресовими ситуаціями була виділена стратегія «уникнення». У $63 \%$ опитуваних нами лікарів різних спеціальностей переважає саме ця стратегія долаючої поведінки (Рис.1).

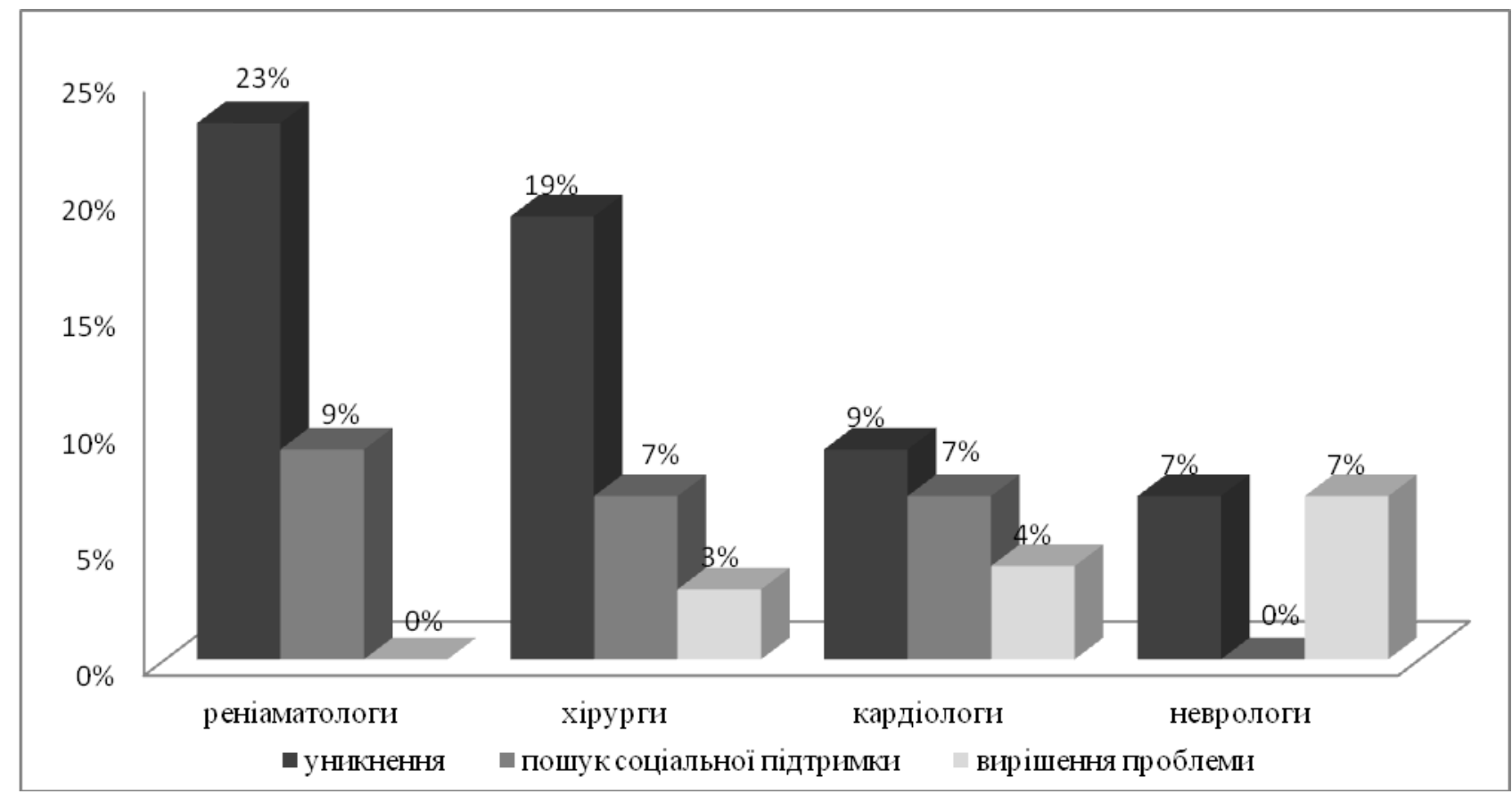

Pис.1. Аналіз домінуючих копінг-стратегій у лікарів різних спеціальностей

Такий результат став для нас досить показовим. Робота лікаря $\epsilon$ надзвичайно важкою і відповідальною, особливо в наш час. Багато 3 них кожного дня виконують фізично і морально надскладні завдання, при цьому зберігаючи спокій для пацієнтів. Але така робота виснажує емоційні ресурси організму. Лікарі завжди залишаються для нас по-справжньому сильними людьми, а тому прагнуть презентувати себе такими тим, хто потребує їх допомоги, осбливо, як показало наше дослідження, лікарі-реаніматологи та лікарі хірургічних спеціальностей, які щодня знаходяться у боротьбі за життя людини. Водночас, копінг-стратегія «уникнення» проявляється у тому, що особистість намагається позбавитися неприємних переживань, викликаних 
стресом за рахунок втечі від їх власного усвідомлення та певної заборони на них. Лікарі прагнуть бути максимально ефективними у своїй щоденній виснажливій праці, проте, власні емоційні стани рефлексуються недостатньо або зовсім витісняються, а як наслідок, поглиблюється емоційне та психологічне виснаження. Стратегія «уникнення» не дозволяє прийняти власний емоційний стан, призводить до тимчасового відходу від проблем, поглиблює фокусування на вирішенні лише професійних завдань, проте не сприяє ефективній психологічній роботі з власними переживаннями, а лише загострює потребу піти від вирішення проблем, забутися. Саме така відмова від роботи зі своїми переживаннями і пояснює той невеликий відсоток опитуваних нами лікарів $(15 \%)$, які використовують копінг-стратегію «вирішення проблем». Можливо, саме це і є однією з причин фізичного виснаження лікаря у професійній діяльності.

На нашу думку, копінг-стратегія «уникнення» $\epsilon$ однією в провідних поведінкових стратегій при формуванні дезадаптивної поведінки особистості. Вона, звичайно, спрямована на подолання або зниження дистресу особистості, однак є далеко не завжди конструктивною. Вважаємо, що використання цієї стратегії зумовлено недостатністю розвитку копінг-ресурсів i навичок активного вирішення проблем, пов'язаних не стільки 3 професійною діяльністю лікаря, скільки 3 його емоційною компетентністю: навичками рефлексії власних емоційних станів та вибору ефективних способів їх переживання.

Звичайно, копінг-стратегія «уникнення» може носити адекватний або неадекватний характер, залежно від конкретної стресової ситуації, професіоналізму та стану ресурсної системи особистості. В ситуації пандемії COVID-19, багато лікарів, пояснюють вибір даної стратегії намаганням змиритися з ситуацією, в яку вони вимушено потрапили, прийняти ऑї, як неминучу, та вчитися співіснувати 3 новими обставинами, які не завжди піддаються впливу та об'єктивному розв'язку, приймаючи їх як свій професійний обов’язок. Саме ця стратегія може особливо проявлятися у деяких видах специфічної професійної діяльності і стає однією 3 провідних поведінкових стратегій при формуванні аддиктивної поведінки, задля зняття стресу та уникнення емоційної напруги.

Результати нашого дослідження показали, що невеликий відсоток опитуваних лікарів (22\%) використовують копінг-стратегію «пошук соціальної підтримки». Щодня кожен лікар збирається 3 думками, приймає поставлене завдання, як частину свого життя, i йде виконувати свій важкий обов'зок. Проте, як показують результати нашого дослідження, фахівці, безумовно, самі потребують допомоги у боротьбі з постійним потоком проблем, що ставить перед ними професія. Тому, копінг-стратегія «пошук соціальної підтримки», завдяки якій людина для ефективного вирішення проблеми звертається за допомогою і підтримкою до оточуючих: друзів, сім’ї, або інших значущих людей, теж обирається тими лікарями, які можуть нею скористатися. 
Варто зазначити, що стійкість, впевненість, самовідданість лікаря є надважливими його професійними компетенціями. Водночас, на нашу думку, проблема полягає у тому, що лікарі важко звертаються за психологічною підтримкою до лікарів-психологів через наявну стигматизацію цієї професії та часто через відсутність такого фахівця у медичному закладі. Тому, питання розробки та впровадження комплексної програми психологічної підтримки сучасного лікаря, яка б включала створення профільної телефонної лінії, центрів психологічної допомоги лікарям, кімнат психологічної релаксації $\epsilon$ актуальними та соціально затребуваними насьогодні.

У ході дослідження, ми також ставили за мету оцінити фактори трудового стресу у лікарів різних спеціальностей, яких ми обрали для дослідження, та їх вплив на вибір домінуючої копінг-стратегії. Для аналізу цього питання нами була використана методика «Опитувальник трудового стресу» (адаптація А.Б.Леонової, С.Б.Величковського), яка дала можливість виявити найбільш поширені стресори, які мають місце у професійній діяльності лікарів різних спеціальностей. Ми підрахували «вагу» кожного стресора (враховуючи його силу та частоту) та виділили основні стресори, які отримали максимальне значення.

Аналізуючи результати, 3 тридцяти стресорів ми змогли виділити шістнадцять найбільш поширених і значущих стресорів (більше 10\%), які призводять до виникнення труднощів та перешкод у роботі лікарів різних спеціальностей. Всі стресори ми розділили на три групи: робочі стресори, міжособистісні та соціальні стресори, рольові стресори. Так до групи робочих нами були віднесені такі найбільш значущі стресори як: підвищена відповідальність, погане обладнання, необхідність приймати термінові рішення, жорсткі терміни виконання завдань, виконання нових, незнайомих завдань, нерівномірність робочого навантаження. Групу соціальних стресорів склали: відсутність підтримки керівництва та схвалення, неадекватне керівництво у кризових ситуаціях, погана підготовка персоналу, погана організація робочого часу, низька заробітна плата. До групи рольових стресорів ми віднесли необхідність працювати за іншого, нестачу особистого часу та неможливість професійного зростання. Решта стресорів набрали не більше 2\%. Аналіз «профілю» стресу і можливість виділення 3-х основних стресорів, які отримали максимальне значення за вагою, показав, що основними стресорами, безперечно, для наших лікарів була група робочих стресорів, серед яких термінове прийняття рішень, виконання нових, незнайомих завдань та підвищена відповідальність набрали найбільший відсоток виборів. Такі фактори, справді, дуже виснажують лікаря як морально, так i фізично, особливо в період пандемії COVID-19. Йому доводиться перебувати в стані постійного напруження, в щоденному очікуванні завдань, які будуть потребувати великих енергозатрат. Водночас, наше дослідження показало, що повсякденні професійні стресові події, підсилюються соціальними та рольовими стресорами, які порушують самопочуття i переживаються як загрозливі, образливі, фруструючі. Відсутність підтримки 3 
боку керівництва чи невдале керівництво, низька заробітна плата та неможливість професійного зростання поглиблюють травмуючі переживання лікаря, сприяють емоційному вигоранню та демотивують лікаря, що пояснює статистику звільнення медичних працівників за власним бажанням в період пандемії COVID-19.

Також, варто зазначити, що такі стресори як наявність кризових ситуацій, погане обладнання і жорсткі терміни виконання завдання викликають не менше стресових ситуацій у лікарів, хоч у вони набрали меншу кількість відсотків (7-8\%). Пандемія COVID-19 поставила медиків у надзвичайно складні професійні умови, в яких кризові ситуації, які потребують миттєвих рішень, і від яких залежить життя багатьох людей стали частиною щоденної роботи лікаря. Опановування нових протоколів лікування хвороби, яка ще не достатньо вивчена та досліджена, поставило ще одне гостре питання наявності, якості та справності обладнання у лікарнях, що насправді може гальмувати термінову роботу лікарів.

Також нами були виділені ті стресори, які найчастіше обирали лікарі різних спеціальностей за методикою «Опитувальник трудового стресу» (адаптація А.Б.Леонової, С.Б.Величковського) (Рис.2.).

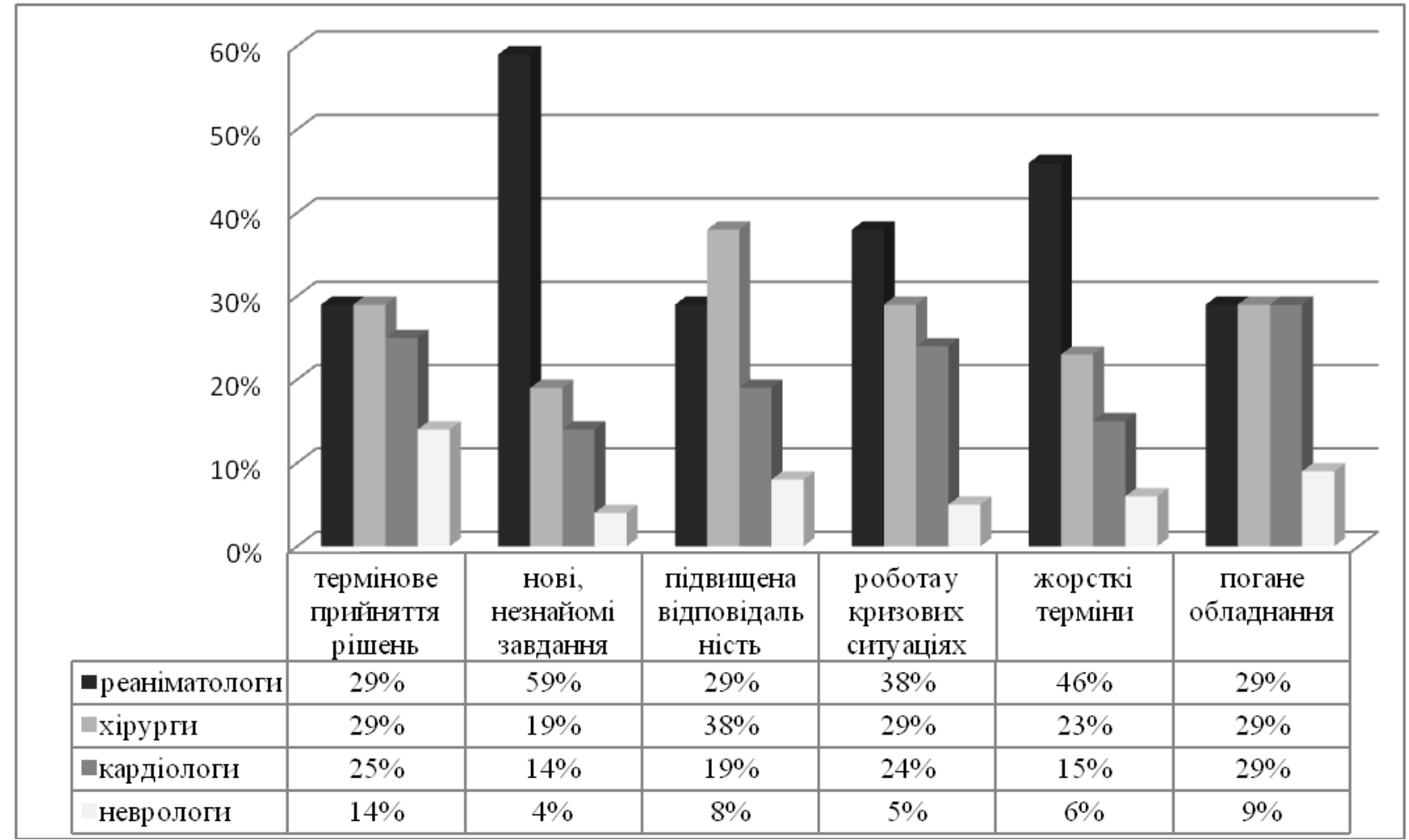

Puc.2. Стресори, які найчастіше були обрані лікарями різних спеціальностей

Як показують результати нашого дослідження, для лікарів-реаніматологів найбільш стресовим фактором були нові незнайомі завдання, які вони змушені виконувати, а також жорсткі терміни виконання роботи, та постійні кризові 
ситуації, у яких опиняються лікарі i по сьогоднішній день. Для хірургів найбільш стресовими факторами були: термінове прийняття рішень, що властиве їх роботі, а також підвищена відповідальність. Щодо лікарівкардіологів, то вони найчастіше також обирали такі стресори, як кризові ситуації на роботі та термінове прийняття рішень. Лікарі-неврологи серед стресорів найчастіше обирали підвищену відповідальність та термінове прийняття рішень. Варто зазначити, що практично всі лікарі різних профілів були одностайними у виборі такого стресору як погане обладнання.

Отож, аналізуючи отримані результати, можна зробити висновок, що дійсно велика кількість стресорів впливає щодня на роботу лікаря, незалежно від його спеціальності. Деякі 3 них, такі як термінове прийняття рішень, кризові ситуації, підвищена відповідальність, нові незнайомі завдання, жорсткі терміни та погане обладнання морально виснажують медичних працівників, змушуючи їх миритися з стресовими ситуаціями, які трапляються, приймати їх, i кожного дня йти на роботу, продовжуючи виконувати сумлінно свій обов'язок.

Водночас, така ситуація виснажує фізичні та психічні ресурси організму та $є$ чинником появи низки негативних переживань таких як напруження, почуття тривоги та почуття провини. Як показали результати нашого дослідження емоційного самопочуття лікарів різного профілю у професійній діяльності за методикою «Вивчення професійної тривоги» (опитувальник Є.Ейдеміллера, І.В.Юстицького) [6], більшість наших досліджуваних перебуває у стані напруженості (66\%), 25\% досліджуваних мали високі показники за шкалою вияву почуття тривоги, почуття провини переживають 9\% наших досліджуваних. На нашу думку, ці результати ще раз підкреслюють ті психологічні ризики, які створює для лікаря їх напружена робота, коли щодня їм доводиться мати справу 3 все більшою кількістю хворих та необхідністю швидко діяти, аби рятувати життя людей. Почуття тривоги провокується невизначеністю ситуації, зачасти неможливістю впливати на перебіг подій та переживанням за власне здоров'я та здоров'я своїх близьких. Що стосується почуття провини, то, здавалося б, відсоток не є великим (9\%), але, на наш погляд, важливим. Цей показник підтверджує наше переконання у тому, що відсутність психологічної підтримки для лікаря часто запускає такі негативні механізми як самозвинувачення, провина, а іноді й аутоагресію. Високі вимоги до професійної компетентності лікаря, відсутність права на помилку та неможливість ефективно відпрацьовувати свої негативні переживання у процесі психологічного супроводу, спричиняє накопичення негативних переживань, а відтак фізичне та емоційне виснаження.

Також нами були проаналізовані емоційні стани лікарів різних спеціальностей (Рис.3). 


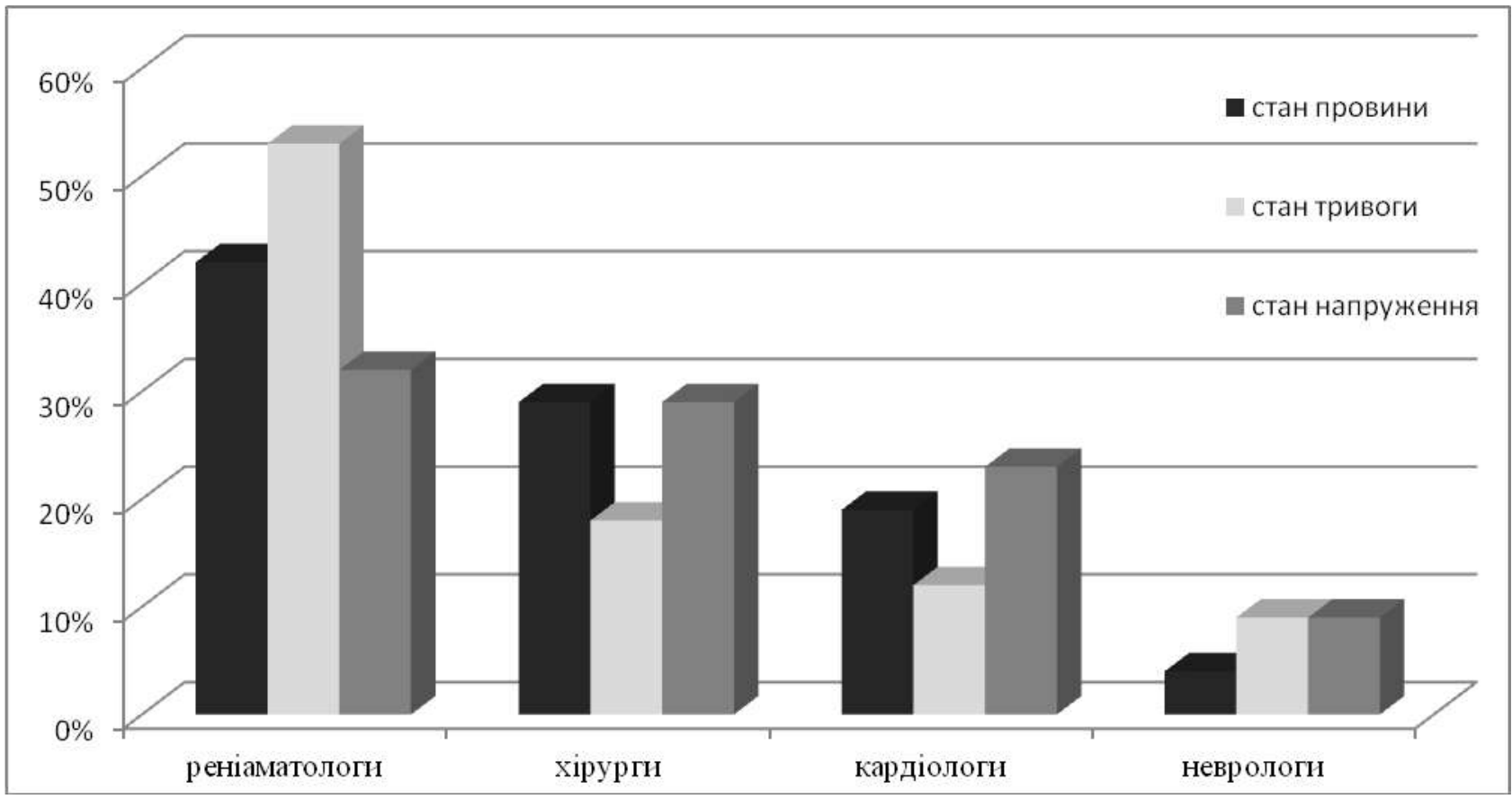

Рис.3. Емоційні стани, характерні для лікарів різних спеціальностей

Як свідчать результати нашого дослідження лікарі-реаніматологи потребують особливої уваги, оскільки для них характерні всі три стани у досить високих показниках. Це пов'язано 3 їх морально важкою роботою щодня, адже вони перші у безпосередній боротьбі за життя людей. Лікаріхірурги та кардіологи, нажаль, теж мають досить високі показники по всім трьом шкалам.

Стан тривоги, напруженості, провини - усе це пригнічує i робить професійну діяльність лікаря ще більш виснажливою та заважає ефективному самоздійсненню.

Висновки. Порівняння результатів за усіма використаними нами методиками свідчить, що для досліджуваних із домінуючою копінг-стратегією «уникнення» характерні високі показники прояву основних стресорів та негативних емоційних станів. Лікарі, не маючи об'єктивної змоги отримати професійну психологічну підтримку, залишаються наодинці 3 проблемою, щодня 3 «холодним розумом» виконуючи свої обов'язки та ризикуючи своїм фізичним і психічним здоров'ям, щоразу виснажуючи ресурси організму. Така ситуація потребує не лише поваги, матеріального і соціального схвалення лікарської діяльності 3 боку держави, а й розробки нових моделей психологічного супроводу діяльності лікаря задля реалізації його професійної ефективності та підтримки психологічної стійкості, задля здоров'я нації, задля нашого майбутнього.

\section{Лimepamypa:}

1. Психодіагностика особистості у кризових життєвих ситуаціях. / В.Л.Зливков, С.О.Лукомська, О.В.Федан. - К.: Педагогічна думка, 2016. - 219с. 
2. Ярош Н. С. Роль рефлексії у процесі подолання стресу особистістю //Психологічний часопис: зб. наук. пр. / за ред. С. Д. Максименка. - Київ, 2017. - № 3 (7). - Вип. 7. - С. 189199. Режим доступу: file:///C:/Users/Administrator/Downloads/3-4-PB.pdf

3. Щербатых Ю.В. Психология стресса и методы коррекции. - СПб.: Питер, 2006. $256 \mathrm{c}$.

4. Кулакевич Т.В. Основні підходи до управління стресовими станами //Психологічні науки: проблеми і здобутки. - 2014. - №5. - С. 35-47. Режим доступу: http://www.irbisnbuv.gov.ua/cgi-

bin/irbis_nbuv/cgiirbis_64.exe?I21DBN=LINK\&P21DBN=UJRN\&Z21ID=\&S21REF=10\&S21C $\mathrm{NR}=20 \& S 21 \mathrm{STN}=1 \& \mathrm{~S} 21 \mathrm{FMT}=\mathrm{ASP} \_$meta\&C21COM=S\&2_S21P03=FILA=\&2_S21STR=Pnpz 2014_5_5

5. Леонова А. Б. Комплексная стратегия анализа профессионального стресса: от диагностики к профилактике и коррекции /А. Б. Леонова // Психологический журнал. 2004. - T. 25. - № 2. - С. 75-85. Режим доступу: http://msupsyj.ru/articles/detail.php?article $=6964$

6. Туріщева Л.В., Гончаренко О.В. Вивчення особистості школяра і педагога. - Х.: «Основа», 2007. - 144c.

\section{References:}

1. Zlyvkov, V.L., Lukomska, S.O., Fedan, O.V.(2016) Psykhodiahnostyka osobystosti u kryzovykh zhyttievykh sytuatsiiakh [Psychodiagnostics of personality in crisis life situations]. K.: Pedagogichna dumka. [in Ukrainian].

2. Iarosh, N. S. (2017) Rol refleksii u protsesi podolannia stresu osobystistiu [The role of reflection in the process of overcoming stress by the individual] S.D.Maksymenko (Eds.), Psykholohichnyi chasopys - Psychological Journal: Scientific Journal of G.S. Kostiyk Institute of Psychology, National Academy of Pedagogical Sciences of Ukraine, 3(7), 189-199. Retrieved from: file:///C:/Users/Administrator/Downloads/3-4-PB.pdf [in Ukrainian].

3. Shherbatyh, Ju.V. (2006) Psykholohyia stressa y metody korrektsyy [Stress psychology and methods of correction]. Saint Petersburg: Piter. [in Russian].

4. Kulakevych, T.V. (2014) Osnovni pidkhody do upravlinnia stresovymy stanamy [Basic approaches to stress management]. Psykholohichni nauky: problemy i zdobutky - Psychological sciences: problems and achievements, 5, 35-47. Retrieved from: http://www.irbis-nbuv.gov.ua/cgibin/irbis_nbuv/cgiirbis_64.exe?I21DBN=LINK\&P21DBN=UJRN\&Z21 ID =\&S21REF=10\&S21C $\mathrm{NR}=20 \& S 21 \mathrm{STN}=1 \& \mathrm{~S} 21 \mathrm{FMT}=\mathrm{ASP} \_\mathrm{meta} \& \mathrm{C} 21 \mathrm{COM}=\mathrm{S} \& 2 \_\mathrm{S} 21 \mathrm{P} 03=\mathrm{FILA}=\& 2 \_\mathrm{S} 21 \mathrm{STR}=\mathrm{Pnpz}$ 2014_5_5 [in Ukrainian].

5. Leonova, A. B. (2004) Kompleksnaia stratehyia analyza professyonalnoho stressa: ot dyahnostyky $\mathrm{k}$ profylaktyke $\mathrm{y}$ korrektsyy [A comprehensive strategy for the analysis of professional stress: from diagnosis to prevention and correction]. Psykholohycheskyi zhurnal Psychological Journal, 25(2), 75-85. Retrieved from: http://msupsyj.ru/articles/detail.php?article=6964 [in Russian].

6. Turishcheva, L.V., Honcharenko, O.V. (2007) Vyvchennia osobystosti shkoliara $i$ pedahoha [The study of the personality of the student and teacher]. X .: «Osnova». [in Ukrainian]. 